\title{
The Influence of OEM's Brand Type (NB vs. PB) on the Brand Attitude and Purchase Intention: Product Type as a Moderator
}

\author{
Eunhye Seong, Ph.D student, Business Administration, Kumoh National Institute of Technology, 61, \\ Daehak-ro, Gumi-si, Gyeongsangbuk-do, 39177, Republic of Korea,dms0749@naver.com \\ *Gwi-Gon Kim, Professor, Business Administration, Kumoh National Institute of Technology, 61, Daehak-ro, \\ Gumi-si, Gyeongsangbuk-do, 39177, Republic of Korea, metheuskim@daum.net \\ *Corresponding author
}

\begin{abstract}
This paper tested the consumer's attitude and Purchase Intention to two brands and the moderating effect of product type. LG is a token of NB (National Brand) and E-Mart is a stimulus for PB (Private brand). But the company in charge of manufacturing in OEM contract is the same and one. Experimental design is as follows: 2 (OEM's Brand type: NB vs. PB) x 2 (Product Type: convenience goods vs. shopping goods). 266 responses were reflected. The results of this study are as follows. First, consumer favored more NB than PB. Second, there was moderating effect of product type. In shopping goods, attitude towards NB was better than PB. But there was no difference in convenience goods. Third, the brand attitude according to OEM's brand type had a positive effect on Purchase Intention. The results of this study suggest a strategic implication for OEM manufacturing. Generally the product quality in NB is perceived better than PB. But there is some difference according to product type. With shopping goods, consumers compare the alternatives and choose the better one, so OEM manufacturer has to choose NB as a strategic alliance partner. Whereas, in convenience goods, consumers nearly don't feel the quality difference between NB and PB, and would rather favor the cheaper one. So OEM manufacturer had better choose anyone which can take advantage of cost leadership. Especially NB can be more influenced by the country of origin and in specialty goods. So research including COO and specialty goods is needed.
\end{abstract}

Keywords: OEM's brand type, Halo effect, Product type, Brand attitude, Purchase intention.

$\begin{array}{lll}\text { Received: 09.12.2020 } & \text { Accepted: 11.01.2021 } & \text { Published: 03.02.2021 }\end{array}$

\section{INTRODUCTION}

Companies strive to save costs and create benefits in an efficient way to cope with rapidly changing environments. One such strategy is to establish factories in Southeast Asia or China where labor costs are comparatively low, or to manufacture products at local factories and export them to other countries. Due to a higher labor cost, price competitiveness is lost in most developed countries.

As such, companies have outsourced their division of labor and specialization in production through the suppliers they contract while they focus on the marketing (distribution). A typical example of this strategy is the OEM (Original Equipment Manufacturing) method. OEM manufactures and sells products made by other companies under its brand name. A company that has production facility only usually use this method when they manufacture and deliver goods ordered from companies in other countries. Trademarks and goodwill are owned by the client while the supplier only manufactures products. Manufacturers use OEM production methods to ensure a positive return on investment based on innovative creation of components [1]. This works in favor of the client who is able to focus on other areas of work by utilizing external resources for their utility and benefit.

There are many OEM companies around the world. There are cases where a single manufacturer produces the products of multiple different brands, which allows for more than one OEM to enlist their services. Foxconn is responsible for most of the research and the developmental side of APPLE iPhones, along with their product delivery, follow-up services, and customer satisfaction. Consumers buy the iPhone based on the brand name APPLE, and as such, they do not buy the iPhone from Foxconn. This is because they judge the quality and characteristics of a product based on the brand attached to the product (halo effect). OEM brands are mainly companies with high-brand awareness. Since companies can change the cost of production through the OEM production method, the effect of reducing production cost can be realized. In other words, by utilizing the expertise of a production company, it is possible to improve product. In the case of OEM manufacturers, not only do they not need to worry about the competition to enter the market with a secured existing customer base, but they can also secure a stable 
market.

These days, many PB are rapidly developing in Korea's consumer goods market, and consumption market. This is because distributors were able to participate in the production of their own products, which is out of the conventional form of distribution where the manufacturer supplies the products. These products are called PB (Private Brand). PB market has grown rapidly based on large a capital and distribution structures. As the sales channels are set in advance, there is no additional promotion fee, so it is ahead of NB products in price competitiveness. Since most of the companies supplying PB are SMEs (small and medium sized businesses) and middle standing businesses, OEM is being placed as a model for a desirable distribution ecosystem. PB will continue to grow, and they plan to increase the proportion of their own brand sales by more than 30\% [2]. In the context of expanding the market of PB products, it is the time when a strategy for shared growth between retailers and manufacturers is needed. A lot of prior studies have been conducted to examine the brand power of $\mathrm{PB}$ and NB, but there are few papers on the products that are produced from a NB's point of view.

Therefore, this study extends the research topic related to the OEM in order to investigate the influence of the OEM's brand type on brand attitude and purchase intention. Regarding to PB and NB products, consumers' product evaluation and consumption behavior can be different. The range of a product's launch has also been expanded from food and household goods to all consumer goods, and the quality has also been improved to a premium equivalent to manufacturer brand (NB; National Brand) products. Therefore, from the perspective of consumers, it can be predicted that in the case of convenience goods and shopping goods, the preference for NB trademark or PB trademark attached to the product will be different. The purpose of this study is to identify brand attitude, purchase intentions, and consumer's attitude, according to OEM's brand type.

\section{Theory and formula}

In this study, we carried out what type of OEM (Original Equipment Manufacturing) brand were preferred by consumers, focusing on order by OEM production methods. In short, Korean consumer attitude were investigated based on the OEM's brand as a NB (NB: National Brand) or a PB (PB: private brand).

\subsection{OEM's brand type on brand attitude}

The corporate brand is the face of product. Strong brands tend to stick in the consumer's mind. The brand not only recognizes the asset value of this but also of their great influence on the consumers' purchase intention. When consumers are attracted to the company's brand power or brand asset, the value of the product increases [3]. When purchasing a product, there are evaluations of alternatives for various brands, but this is because purchasing decisions are made based on purchasing motives and purchasing ability toward only the brands they prefer. This can be explained by Fishbein's attitude model. The OEM production method is used by utilizing the halo effect of the brand's asset value.

The halo effect is where the first encounter with an object affects its evaluation by the consumer. When evaluating an object or a person, the overall evaluation varies by a part of the object. This is because when an objective product comparison is difficult to deduce, the consumer uses the external information of the brand to make their decision [4]. There are many experiments that have proved the halo effect. Typically, there is an experiment on books. It is an experiment that sells the same book with different cover. One cover uses the prestige of 'Harvard University' and the other cover leaves this off. The books with 'Harvard University' on them sell more copies. The halo effect makes people perceive the quality of a product similarly to how they value the OEM brand. This increases the preference for a product based on the confidence the consumer has in the brand attached to the product [5]. Consumers view the brand attached to the product and judge the product quality and characteristics (halo effect). That is, when purchasing unfamiliar products, the consumer's attitude can be more unfavorable toward an unknown brand [6]. This is because the more well-known and famous other brands are, the better the consumer will think of the product [7].

However, consumers' attitude is not similar just because a brand is famous. This is because the consumer has a difference in value between PB and NB [8]. In one study, PB products were packaged like NB products and presented to consumers at NB'S price, which received good reviews. Conversely, when NB was presented and packaged like a PB product, the consumer's evaluation of the quality was negative. This is because the brand power of NB is stronger than that of PB. While PB has the advantage of lower prices than NB $[8,9]$, consumers are reluctant to buy PB because they have concerns about the quality. This is because the quality of a PB product is perceived to be less than that of a NB's. Consumers are more likely to prefer NB than PB [10].

In this study, it was judged that attitude toward NB would be more favorable than toward PB because of 
their high awareness and association through the halo effect. Accordingly, the following hypothesis was established.

Hypothesis 1: NB will have a higher brand attitude than PB.

\subsection{Moderating effect of product type}

Product types are divided into B2B (Business to Business) and B2C (Business to Consumer) depending on the consumer base and product usage. B2C can be divided into convenience goods, shopping goods, and specialty goods depending on the characteristics of the consumers $[11,12]$. Convenience goods are items that are purchased without worrying about when they are needed. Shopping goods are products that show the purchasing behavior that can be determined after comparing several products. Specialty goods are products that are relatively expensive and exhibit buying behavior characteristics of brand insistence to accommodate only specific brands. This study empirically analyzed convenience goods and shopping goods, excluding specialty goods when they preferred only specific brands among B2C.

Consumer behavior, such as ease of attitude change and brand preference, varies according to B2C. In short, Brand attitude according to OEM's brand type will be moderated by product type. In the case of convenience goods, consumers prefer easy to buy and low priced brand products because they can purchase them without worry. Consumers often tend to prefer PB because they perceive them to be more accessible and inexpensive and of a decent quality. So, In the case of convenience goods, the attitude toward PB will be higher than that of NB. On the other hand, shopping goods are expensive compared to convenience goods, and have higher quality product differences, so they would prefer NB with high quality than PB [13]. In the case of shopping goods, the attitude toward NB will be higher than that of PB. Based on these previous studies, the following hypotheses were established in this study.

Hypothesis 2: The effect of OEM's brand Type on Brand attitude will be moderated by Product type.

\subsection{Brand attitude on purchase intention}

In terms of marketing, attitude has an important meaning. This is because consumers express their emotions through attitude when they like or dislike certain products and services. Consumer brand attitude is used as a useful variable in predicting purchase intention. It is because in the first purchase of a specific product, the attitude toward the brand is formed and then a future purchase decision is made for the product.

Consumer attitude toward a product is an important variable to predict the purchase intention and purchase probability, and the more favorable the consumer's attitude is, the higher the purchase intention and purchase probability will become. Brand attitude has a positive effect on the attitude toward a specific product and such positive attitude is likely to lead to purchase intention.

Purchase intention is a concept that collects a consumer's interest in a brand and evaluates the possibility of purchasing the brand's product and services, which is different from the brand attitude that shows either a favorable or unfavorable tendency toward the brand. Attitude can be categorized into cognitive, emotional, and behavioral factors. According to the Cognitive Learning Theory, consumers form an attitude toward the attributes of product by their beliefs and decide whether or not to purchase it. In other words, consumers go through the steps of attribute belief - attitude - purchase intention of product. Brand perceptions of product quality have an impact on perceived value and purchase intention [14]. Brand attitude and purchase intention are highly correlated [15]. The more favorable the consumer's attitude toward the brand is, the stronger it affects the purchase intention [16]. Based on these previous studies, the following hypothesis was established in this study.

Hypothesis 3: Brand attitude on OEM will have a positive effect on purchase intention.

\subsection{Research model}

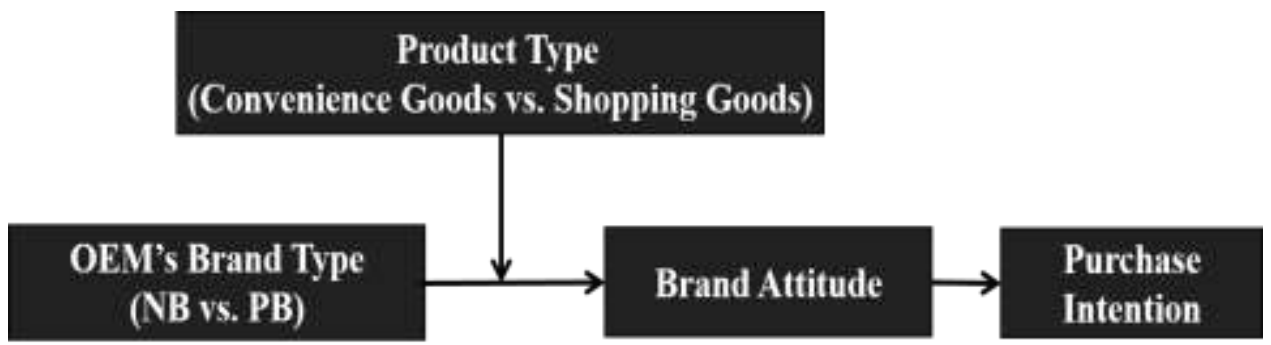

Figure 1. Research Model. 


\section{Experimental setup}

\subsection{Experiment design and measurement of variables}

To test the above hypotheses, this study was carried out for the general population and stu dents living in Korea. Experimental design is as follows: This paper produced 4 types of adv ertisement as stimulants by designing 2 (OEM's Brand type: NB vs. PB) x 2 (Product Type: convenience goods vs. shopping goods). Stimulants used in the research are real products in the Korean market. By conducting the Focus Group Interview (FGI) to 24 researchers in the Global Business Consulting lab in Business Administration Department, Kumoh National Institut e of Technology, this research was stimulated. By providing respondents with the Mask packs , this research led them to respond sincerely to the questions. Among 300 copies of the que stionnaire, this research used 266 copies for final analysis excluding some problematic copies.

\subsubsection{Selection of Stimulus}

For this study, real brand such as LG and E-Mart was used. LG is a token of NB (National Brand) and E-Mart is a stimulus for PB (Private brand). But the company in charge of ma nufacturing in OEM contract is the same and one. Toothpaste and an LED TV were selected as Convenience goods and Shopping goods products respectively through a preliminary surve y. As an OEM brand, E-Mart, a large distributor and LG Electronics and LG H\&H, affiliates of the LG Group were selected respectively.

In the case of $\mathrm{PB}$, Convenience goods selected the E-plus toothpaste being sold at E-Mart, an $\mathrm{d}$ respectively, the E-Mart No-brand LED TV was selected as the Shopping goods. In the case of NB, RICH brand toothpaste being sold by LG H\&H was selected as the Convenience good $\mathrm{s}$, and respectively, the LG SIGNATURE LED TV being sold by LG Electronics was selected as the Shopping goods. The actual price the items were being sold at was investigated in adv ance to express reality. The Ad message which they could see frequently was used as Ad co pies.

The statistical package program SPSS 21.0 was used to conduct the empirical analysis. Factor analysis and reliability tests were conducted to verify the validity of the analysis of the res ults of specific statistics. Cronbach's alpha was used for reliability. T-test was used to verify the relationship between OEM's brand type (NB vs. PB) and brand attitude, and ANOVA was used to verify moderating effects of the product type. The verification of the parameters an $\mathrm{d}$ the dependent variables was carried out by regression analysis (linear). The characteristics of the sample were analyzed by descriptive statistics (frequency analysis), showing the numbe $r$ of respondents in percentage (\%) and cumulative percentage (\%). The items included in th e questionnaire were Product Type, Brand Attitude, Purchase Intention, and Demographic Vari ables.

\section{Result discussions}

\subsection{Verification of validity and reliability}

Prior to the test of the hypothesis, this study measured multiple items to see if the items a pplied in the constructed variables were accurately measured. Therefore, we conducted a fact or analysis of these variables, which required validation. The variables of factor analysis inclu ded brand attitude, and purchase intention. Internal consistency was secured by using Cronba ch's alpha coefficient for reliability.

\subsection{Verification of hypothesis 4.2.1. Verification of hypothesis 1}

Hypothesis 1: NB will have a higher brand attitude than PB.

T-test was conducted for Hypothesis 1 for group-to-group mean comparisons. National OEM brand and Private OEM brand were analyzed as independent variable, and brand attitude was analyzed as dependent variables. The statistical results are shown in [Table 1].

Table 1. Brand attitude according to OEM's brand type (t-test)

\begin{tabular}{l|l|l|l|l|l}
\hline OEM's brand Type & $\mathrm{n}$ & $\mathrm{m}$ & S.D & $\mathrm{t}$ & $\mathrm{p}$
\end{tabular}




\begin{tabular}{l|l|l|l|l|l}
\hline $\begin{array}{l}\text { PB } \\
\text { (Private Brand) }\end{array}$ & 132 & 4.34 & .955 & -3.699 & .00 \\
\hline $\begin{array}{l}\text { NB } \\
\text { (National Brand) }\end{array}$ & 134 & 4.80 & 1.007 & & \\
\hline
\end{tabular}

Brand attitude according to OEM's brand Type were statistically significant as MPB_OEM $=4.34$, MNB_OEM $=4.80, t=-3.699, p<.05$. Hypothesis 1 was adopted because the attitude toward national OEM brand was higher than that of private brand. The result is shown in [Figure 2].

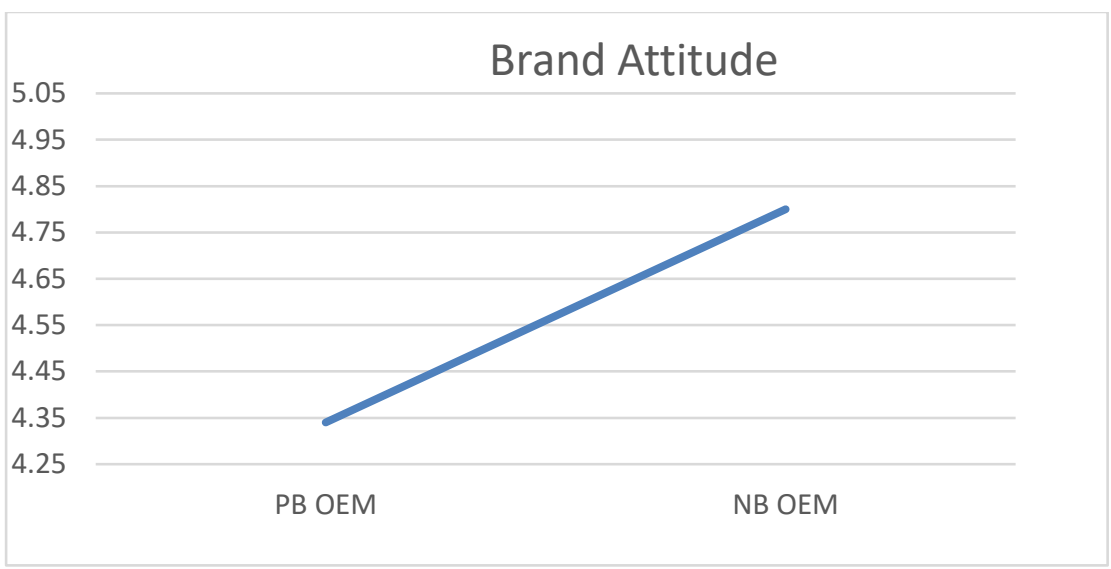

Figure 2. Brand attitude on OEM's brand type

\subsubsection{Verification of hypothesis 2}

Hypothesis 2: The effect of OEM's brand Type on Brand attitude will be moderated by Product type.

In order to verify the regulatory effect of Hypothesis 2, one-way analysis of variance (ANOVA) was conducted to verify the interaction of dependent variables of two groups. OEM's brand applied two type (NB vs. $\mathrm{PB}$ ) as independent variables, Product type as control variable, and brand attitude as dependent variable. The interaction effect between OEM's brand Type and Product type was $F=5.993, p<.05$. This indicates that the OEM's brand is regulated by the distributor OEM brand and the manufacturer OEM brand according to the product type. The results are shown in [Table 2].

Table 2. Moderating effect between OEM's brand type and product type (ANOVA)

\begin{tabular}{l|l|l|l|l|l}
\hline & $\begin{array}{l}\text { Sum of } \\
\text { Squares }\end{array}$ & $\begin{array}{l}\text { Degree of } \\
\text { Freedom }\end{array}$ & Mean Square & $\mathrm{F}$ & $\mathrm{p}$ \\
\hline OEM's brand Type(a) & 8.118 & 1 & 8.118 & 8.311 & .00 \\
\hline Product Type (b) & 1.788 & 1 & 1.778 & 1.833 & .17 \\
\hline $\mathrm{a}$ b & 5.847 & 1 & 5.847 & 5.993 & .01 \\
\hline Error & 241.044 & 247 & & & \\
\hline Total & 5458.782 & 251 & & & \\
\hline Total after modification & 258.814 & 250 & & & \\
\hline
\end{tabular}

T-test was conducted to compare the mean value of the two groups of Convenience goods and Shopping goods. The results of the analysis are shown in [Table 2-1]. In the case of Convenience goods, the brand attitude according to OEM's brand Type was not statistically significant as MPB_OEM $=4.43$, MNB_OEM = $4.48, t=-.329, p>.05$. On the other hand, in the case of Shopping goods, the brand attitude according to OEM's brand Type was MPB_OEM $=4.43$, MNB_OEM $=4.48, \mathrm{t}=-3.709, \mathrm{p}<.05$ There was a statistically significant difference. This means that the attitude toward NB brand is higher than that of PB. 
Table 2-1. Moderating effect between OEM's brand type and product type (t-test)

\begin{tabular}{l|l|l|l|l|l|l}
\hline Classification & OEM's brand Type & $\mathrm{n}$ & mean & S.D & $\mathrm{t}$ & $\mathrm{p}$ \\
\hline $\begin{array}{l}\text { Convenience } \\
\text { goods }\end{array}$ & PB(Distributor) & 60 & 4.43 & .849 & & \\
\cline { 2 - 7 } & $\mathrm{NB}$ (Manufacturer) & 51 & 4.48 & .905 & -.329 & .74 \\
\hline $\begin{array}{l}\text { Shopping } \\
\text { goods }\end{array}$ & PB(Distributor) & 69 & 4.29 & 1.12 & & \\
\cline { 2 - 7 } & $\mathrm{NB}$ (Manufacturer) & 71 & 4.96 & 1.02 & -3.709 & .00 \\
\hline
\end{tabular}

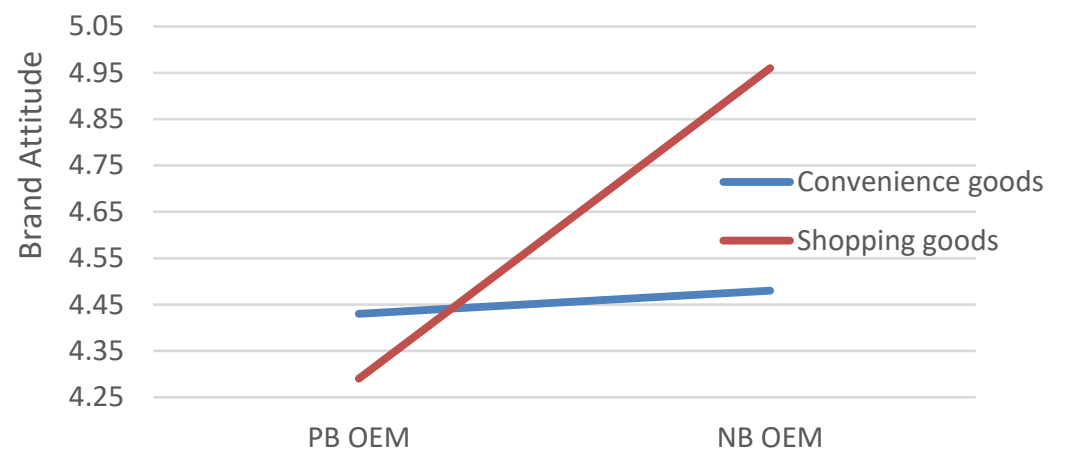

Figure 3. Moderating effect between OEM's brand type and product type

\subsubsection{Verification of hypothesis 3}

Hypothesis 3: Brand attitude on OEM will have a positive effect on purchase intention.

A regression analysis was carried out for Hypothesis 3. The analysis results are shown in [Table 3]. For the purchase intention, the explanatory power $\left(\mathrm{R}^{2}\right)$ was $0.399(39.9 \%)$ and the $\mathrm{F}$ value was $175.207 \mathrm{p}=$ 0.000 ). The brand attitude, which is an independent variable, showed $\beta=.632, p<.05$, indicating a statistically significant positive effect. Therefore, Hypothesis 3 was adopted.

Table 3. Purchase intention according to brand attitude (Regression Analysis)

\begin{tabular}{l|l|l|l|l|l|l}
\hline $\begin{array}{l}\text { Independent } \\
\text { variables }\end{array}$ & $\begin{array}{l}\text { Dependent } \\
\text { Variables }\end{array}$ & S.D & $\beta$ & $\mathrm{t}$ & $\mathrm{p}$ & Statistics \\
\hline \multirow{3}{*}{$\begin{array}{l}\text { Brand } \\
\text { Attitude }\end{array}$} & (Constant) & .780 & & 3.086 & .02 & $\begin{array}{l}\mathrm{R}^{2}=.399 \\
\text { Modified } \mathrm{R}^{2}=.397 \\
\end{array}$ \\
\cline { 2 - 7 } & $\begin{array}{l}\text { Purchase } \\
\text { Intention }\end{array}$ & $\begin{array}{l}.714 \\
.054\end{array}$ & .632 & 13.235 & .00 & \\
\hline
\end{tabular}

Table 4. Summary of verification results of hypotheses

\begin{tabular}{l|l|l|l} 
Classification & Description & $\begin{array}{l}\text { Analysis } \\
\text { Method }\end{array}$ & Result \\
\hline
\end{tabular}




\begin{tabular}{l|l|l|l}
\hline Hypothesis1 & NB will have a higher brand attitude than PB. & t-test & Adopted \\
\hline Hypothesis2 & $\begin{array}{l}\text { The effect of OEM's brand Type on Brand attitude will be } \\
\text { moderated by Product type. }\end{array}$ & ANOVA & Adopted \\
\hline Hypothesis3 & $\begin{array}{l}\text { Brand attitude on OEM will have a positive effect on } \\
\text { purchase intention. }\end{array}$ & $\begin{array}{l}\text { Regression } \\
\text { Analysis }\end{array}$ & Adopted \\
\hline
\end{tabular}

\section{Conclusion}

This study examines the effect of OEM's brand type on brand attitude and purchase intention through empirical analysis. Unlike previous studies, it was controlled by product type (convenience goods vs. shopping goods). Empirical analysis results showed that 1) Consumer favored more NB (National Brand) as an OEM's brand type than PB (Private Brand). 2) There was moderating effect of product type. In the case of shopping goods, attitude towards NB was better than PB. But there was no difference between NB and PB. 3) The brand attitude according to OEM's brand type had a positive effect on Purchase Intention. Previous studies said in the case of convenience goods, it is said that consumers prefer PB because they are recognized as more easily accessible, inexpensive, and decent quality. But this study confirmed that there was no difference. In the case of convenience goods, since they are habitually purchased and show no positivity and prudence in information search and alternative evaluation, price is more important than brand.

The result suggests a strong implication for OEM manufacturing. Practical implications are as follows. First, since consumers are influenced by the brand halo effect, in the case of shopping goods, aggressive brand exposure advertisement utilizing their own brand halo effect will be more effective for NB. In other words, strategic marketing which increases brand exposure, will not only help consumers in many ways, but will also bring the same benefits to manufacturers. With shopping goods, recognition of excellence in product quality is important, so a partnership strategy with National brands is necessary. Second, in the case of convenience goods, both PB and NB will need a marketing strategy of enlargement and cost leadership so that consumers can easily access them. That is, due to the advantages of the OEM production method, in the case of $\mathrm{PB}$ and NB, it can be seen that the OEM product market can be developed relatively easily and the possibility of success is high.

Despite these implications, there are three limitations. 1) There was no operational check on awareness of stimulants (LG vs. E-mart). Tried to overcome it by applying market research and the actual selling price. 2) Limited to domestic OEM products. 3) Type of product was considered only. It would have been better to consider overall consumer's appraisal and the perceived price and quality of the product. In connection with this study, several future research tasks can be suggested. The author only looked at the brand Halo Effect. The country of origin of the product through OEM can also be a factor that can't be ignored. 1) It can be controlled by the country of origin. In this study, product type of convenience goods and shopping goods were only used. In the future, 2) additional items need to be checked by the OEM's brand type for specialty goods.

\section{References}

1. Joshi, Ashwin W. "OEM implementation of supplier-developed component innovations: the role of supplier actions." Journal of the Academy of Marketing Science 45, no. 4 (2017): 548-568.

2. Levy, Michael, Barton A. Weitz, and Dhruv Grewal. Retailing management. New York, NY: Irwin/McGraw-Hill, 1998.

3. Farquhar, Peter H. "Managing brand equity." Marketing research 1, no. 3 (1989).

4. Hoch, Stephen J. "How should national brands think about private labels?." MIT Sloan Management Review 37, no. 2 (1996): 89.

5. Erdem, Tülin, and Joffre Swait. "Brand Equity as a Signaling Phenomenon, 7 J." CONSUMER PSYCHOL 131 (1998).

6. Vaidyanathan, Rajiv, and Praveen Aggarwal. "Strategic brand alliances: implications of ingredient branding for national and private label brands." Journal of Product \& Brand Management (2000).

7. Baker, Julie, Dhruv Grewal, and Ananthanarayanan Parasuraman. "The influence of store environment on quality inferences and store image." Journal of the academy of marketing science 22, no. 4 (1994): 328-339.

8. Ailawadi, K. L., Neslin, S. A., \& Gedenk, K. (2001). Pursuing the value-conscious consumer: store brands 
versus national brand promotions. Journal of marketing, 65(1), 71-89.

9. Richardson, Paul S., Arun K. Jain, and Alan Dick. "Household store brand proneness: a framework." Journal of retailing 72, no. 2 (1996): 159-185.

10Liu, Richie L., David E. Sprott, Eric R. Spangenberg, Sandor Czellar, and Kevin E. Voss. "Consumer preference for national vs. private brands: The influence of brand engagement and self-concept threat." Journal of Retailing and Consumer Services 41 (2018): 90-100.

11. Bucklin, Louis P. "Retail strategy and the classification of consumer goods." Journal of marketing 27, no. 1 (1963): 50-55.

12. Copeland, Melvin T. "Relation of consumers' buying habits to marketing methods." Harvard business review 1, no. 2 (1923): 282-289.

13. Quelch, John A., and David Harding. "Brands versus Private labels-Fighting to win"." (1996).

14. Calvo-Porral, Cristina, and Jean-Pierre Lévy-Mangin. "Store brands' purchase intention: Examining the role of perceived quality." European Research on Management and Business Economics 23, no. 2 (2017): 90-95.

15. Achenbaum, Alvin A. "Effective exposure: A new way of evaluating media." In Association of national advertisers media workshop, new york. 1977.

16. Spears, Nancy, and Surendra N. Singh. "Measuring attitude toward the brand and purchase intentions." Journal of current issues \& research in advertising 26, no. 2 (2004): 53-66. 